\title{
PENINGKATAN HASIL BELAJAR SISWA ASPEK KOGNITIF DAN PSIKOMOTORIK DALAM MEMBUAT SKETSA DAN PETA WILAYAH YANG MENGGAMBARKAN OBJEK GEOGRAFI MELALUI METODE SURVEI LAPANGAN
}

\author{
Woro Kristiningtyas ${ }^{\varpi}$
}

SMP Negeri 2 Jakenan

\section{Info Artikel Abstract}

Sejarah Artikel:

Diterima 31 Okt 2017

Disetujui 22 Nov 2017

Dipublikasikan Des 2017

\section{Keywords:}

Field survey, cognitive, psychomotor

\begin{abstract}
This study aims to increase student learning of cognitive and psychomotor aspects in making sketches and maps of the area that describes the object of geography in class VII B SMP N 2 Jakenan. The research was conducted inside and outside the classroom to conduct a field survey around the school and village offices Glonggong. The research subject is class VIIB conducted with two cycle cycles, each cycle consisting of planning, acting, observing and reflecting. The research proves that the application of a field survey methods can improve student learning outcomes on cognitive aspects with an average grade of 53.32 - 69.19 to 78.55 ; psychomotor aspect was no increase in the average grade of 58.00 to $70.81-79.52$ with indicators increase students' ability to collect data, geography placing objects in the image, complete the elements of sketches and maps of the area and were able to finish the sketches and maps of the area the aesthetic value according to the rules cartographical correct. It is concluded that the cognitive aspects of student learning outcomes and psychomotor aspects can be improved through a field survey methods.
\end{abstract}

\begin{abstract}
Abstrak
Tujuan penelitian ini untuk meningkatkan hasil belajar siswa aspek kognitif dan aspek psikomotorik dalam membuat sketsa dan peta wilayah yang menggambarkan objek geografi pada siswa kelas VII B SMP N 2 Jakenan. Penelitian ini dilaksanakan di dalam dan di luar kelas dengan melakukan survei lapangan di sekitar lingkungan sekolah dan kantor desa Glonggong. Subjek penelitian adalah kelas VIIB yang dilaksanakan dengan 2 siklus, tiap siklusnya terdiri dari planning, acting, observing dan reflecting. Hasil penelitian membuktikan bahwa penerapan metode survei lapangan dapat meningkatkan hasil belajar siswa pada aspek kognitif dengan ratarata kelas dari 53,32 - 69,19 - 78,55; sedang aspek psikomotorik ada peningkatan rata-rata kelas dari 58,00 - 70,81 - 79,52 dengan indikator peningkatan kemampuan siswa dalam mengumpulkan data, menempatkan objek geografi pada gambar, melengkapi unsur sketsa dan peta wilayah serta mampu menyelesaikan gambar sketsa dan peta wilayah yang bernilai estetis sesuai kaidah kartografis yang benar. Kesimpulan penelitian ini adalah hasil belajar siswa aspek kognitif dan aspek psikomotorik dapat meningkat melalui metode survei lapangan.
\end{abstract}

(C) 2017 Universitas Muria Kudus

Program Studi Pendidikan Guru Sekolah Dasar

Fakultas Keguruan dan Ilmu Pendidikan Universitas Muria Kudus

Kampus UMK Gondangmanis, Bae Kudus Gd. L. 1t I PO . BOX 53

Kudus

Tlp (0291) 438229 ex.147 Fax. (0291) 437198

E-mail: worokristiningtyas@yahoo.co.id. 


\section{PENDAHULUAN}

Pelaksanaan pembelajaran KD 4.2. mengenai membuat sketsa dan peta wilayah yang menggambarkan objek geografi serta disampaikan dengan metode ceramah di dalam kelas membuat siswa cenderung belajar secara teori saja. Otak siswa dipaksa untuk mengingat dan menimbun berbagai informasi kartografi tanpa memahami aplikasi di kehidupan nyata.

Pembelajaran yang tersebut diatas berakibat pada kekurangmampuan siswa mempraktikkan dalam menggambar sketsa dan peta wilayah sesuai dengan aturan kartografis yang benar. Siswa kurang menggali secara mendalam fenomena alam yang ada di lingkungan belajar khususnya berkaitan dengan pengetahuan perpetaan.

Melihat kondisi tersebut, maka pembelajaran yang variatif perlu diciptakan oleh guru guna meningkatkan hasil belajar maupun kemampuan menggambar sketsa. Salah satu wujud pembelajaran yang variatif adalah dengan pemanfaatan lingkungan sebagai sumber belajar agar tercapai tujuan pembelajaran yang diinginkan. Oleh karena itu, guru harus mampu menyiapkan siswa secara kognitif, afektif dan psikomotorik melalui perencanaan pembelajaran yang matang serta selalu melakukan inovasi.

Berdasarkan hasil observasi serta data ulangan harian maupun tugas-tugas yang terkumpul dalam membuat sketsa dan peta wilayah yang menggambarkan objek geografi pada siswa kelas VIIB tahun pelajaran 2015/2016 diketahui bahwa rata-rata hasil belajar siswa belum mencapai kriteria ketuntasan minimal (KKM) yang ditetapkan yakni sebesar 75. Hasil belajar siswa aspek kognitif yang dicapai siswa rata-rata sebesar 53,33 dan hasil belajar siswa aspek psikomotorik yang dicapai siswa memiliki kategori Cukup $(58,00)$ berada pada rentang nilai 56-70. Pada aspek psikomotorik, nilai siswa masih tergolong rendah. Siswa belum mampu menghasilkan produk sketsa dan peta wilayah yang berkualitas, belum mampu mengambil data primer yang bersumber dari hasil survei lapangan untuk diterapkan langsung pada gambar sketsa dan peta wilayah.

Rendahnya hasil belajar siswa aspek kognitif dan psikomotorik merupakan sesuatu yang menarik untuk dikaji, sehingga peneliti perlu mencari solusinya. Usaha yang bisa dilakukan guru yaitu mengganti metode ceramah yang dilakukan di dalam kelas dengan metode survei lapangan.

Data yang diperoleh di lapangan perlu diuji kualitanya, sehingga perlu dilakukan triangulasi data dengan penggunaan fasilitas
Google Map. Google Map bermanfaat untuk membandingkan data primer di lapangan dengan data sekunder berupa peta digital yang didapat dari Google Map. Penggunaan Google Map sebagai penunjang dalam mengecek akurasi data, bentuk lahan dan objek geografi yang tergambar di peta digital dengan kenyataan langsung di lapangan sangatlah penting.

Penerapan metode survei lapangan sebagai usaha memperbaiki rendahnya hasil belajar siswa kelas VIIB tahun pelajaran 2015/2016 pada aspek kognitif dan psikomotorik didukung oleh pendapat Dale dan Finn. Dale mengemukakan tentang Kerucut Pengalaman (Cone of Experience) yang menyatakan bahwa pengalaman yang bersifat langsung hasilnya lebih baik daripada pengalaman melalui simbolsimbol komunikasi, merentang dari yang bersifat kongkrit ke abstrak. Pernyataan tentang kerucut pengalaman Dale didukung Trianto (2007: 34) yang mengungkapkan bahwa pengalaman belajar secara langsung itu sebagian besar (90\%) akan diingat bila diperoleh melalui kegiatan praktek (melakukan) dan diungkapkan (dikatakan) oleh orang lain. Pengalaman belajar yang diperoleh dengan membaca, yang mampu diingat hanya $10 \%$.

Sanjaya (2009:165) menjelaskan bahwa pengalaman langsung merupakan pengalaman yang diperoleh siswa sebagai hasil dari aktivitas sendiri. Siswa mengalami, merasakan sendiri segala sesuatu yang berhubungan dengan pencapaian tujuan. Siswa berhubungan langsung dengan objek yang hendak dipelajari tanpa menggunakan perantara untuk digeneralisasi dalam bentuk mind map. Pengalaman langsung inilah ada kecenderungan hasil yang diperoleh siswa menjadi konkret sehingga akan memiliki ketahanan di otak siswa dan masuk ke memori jangka panjang.

Berdasarkan latar belakang diatas rumusan masalah dalam penelitian ini yaitu Apakah penerapan metode survei lapangan dapat meningkatkan hasil belajar siswa aspek kognitif dan aspek psikomotorik dalam membuat sketsa dan peta wilayah yang menggambarkan objek geografi pada siswa kelas VIIB tahun pelajaran 2015/2016? Tujuan penelitian ini yakni untuk mendeskripsikan peningkatan hasil belajar siswa aspek kognitif dan psikomotorik dalam membuat sketsa dan peta wilayah yang menggambarkan objek geografi pada siswa kelas VIIB tahun pelajaran 2015/2016 melalui metode survei lapangan.

\section{METODE PENELITIAN}

Penelitian ini tergolong pada classroom action research yang merupakan pengkajian 
terhadap permasalahan praktis bersifat situasional dan kontekstual dengan 2 siklus. Penelitian ini menggunakan model Kurt Lewin (dalam Setiadi, 2014: 6) terdiri dari empat komponen, yaitu (1) perencanaan (planning), (2) tindakan (acting), (3) pengamatan (observing), dan (4) refleksi (reflecting).

Subjek penelitian ini yakni siswa kelas VIIB tahun pelajaran 2015/2016 semester genap, yang berjumlah 31 siswa terdiri dari 19 laki-laki dan 12 perempuan. Adapun pertimbangan mengambil subjek penilitian pada kelas VIIB yang merupakan kelas unggulan seharusnya nilainya lebih unggul dari pada kelas reguler lainnya, namun pada kenyataannya kelas VIIB nilainya masih dibawah KKM yaitu nilai ratarata kelas hasil ulangan 53,33 dan aspek psikomotorik masih tergolong kategori cukup.

Data primer berasal dari penelitian langsung dilapangan dengan peninjauan objekobjek geografi baik objek alami maupun objek buatan/sosial. Data sekunder diambil dari dokumen berupa: berbagai contoh gambar sketsa di undangan, Peta desa Glonggong yang berada di kantor desa, Peta digital dari Google Map dan Peta yang berasal dari Laboratorium Geografi UNNES Semarang.

Data yang diperlukan dalam penelitian ini adalah data hasil tes dan non tes saat kegiatan pembelajaran berlangsung maupun setelah selesai kegiatan pembelajaran. Data tes diperoleh dengan melihat hasil ulangan siswa setelah melakukan pembelajaran dan data non tes diperoleh dengan menggunakan teknik observasi saat proses pembelajaran berlangsung sampai produk yang dihasilkan siswa.

Instrumen dalam penelitian ini berbentuk tes dan nontes. Tes tersebut berupa tes objektif tertulis dengan 4 pilihan jawaban dan sesekali pula dilakukan tes lisan disesuaikan dengan materi pembelajaran yang sedang dilaksanakan. Tes tertulis meliputi aspek: (1) pengetahuan umum tentang perpetaan; (2) unsur-unsur yang harus ada pada sketsa dan peta wilayah; (3) penerapan simbol yang menggambarkan objek geografi; (4) manfaat dan penerapan sketsa dan peta wilayah bagi kehidupan masa kini. Pembelajaran materi sketsa dan peta wilayah dianggap berhasil apabila siswa memperoleh nilai KKM 75. Pembelajaran dianggap tuntas klasikal bila 75\% siswa menguasai kompetensi.

Instrumen nontes dalam penelitian ini berbentuk pedoman observasi kegiatan survei lapangan. Unsur-unsur yang diobservasi meliputi: (1) Kemampuan siswa dalam pengumpulan data. Data yang dimaksud adalah data primer dan data sekunder. Siswa yang mampu mengumpulkan data dengan lengkap diberi skor 5; (2) Kemampuan siswa dalam penempatan objek geografi. Objek geografi terdiri dari objek alami (areal pertanian, sungai, batas desa) maupun objek buatan/sosial seperti pasar, sekolah, balai desa dan tempat ibadah. Siswa yang mampu mengumpulkan data objek geografi dengan lengkap diberi skor 5; (3) Kemampuan siswa dalam melengkapi unsurunsur sketsa dan peta wilayah seperti orientasi mata angin, judul, skala, simbol, legenda, inset, garis border. Siswa yang mampu mencantumkan unsur-unsur sketsa dan peta wilayah dengan lengkap diberi skor 5; (4) Tahap finishing, penyelesaian gambar dengan pewarnaan atau penyelesaian unsur-unsur yang lain yang bernilai estetis guna memperindah tampilan gambar sketsa dan peta wilayah. Gambar yang bernilai estetis tinggi diberi skor 5 .

Pengambilan data aspek psikomotorik siswa disediakan lembar rubrik penilaian tiap siswa satu lembar dengan identitas nama dan nomor absen. Guru mengisi lembar tersebut dengan skoring. Skor yang digunakan adalah rentang 1-5.

Sebelum instrumen penelitian dipergunakan perlu diuji kesahihannya terlebih dahulu. Uji kesahihan instrumen penelitian ini dilakukan dengan uji validitas permukaan dan validitas konten dengan menyesuaikan instrumen dengan kisi-kisi penulisan soal.

Uji validitas selain tersebut di atas juga menggunakan validitas proses Validitas proses merupakan tindakan yang dilakukan peneliti dalam memecahkan masalah (Setiadi, 2014:14). Validitas proses berhubungan dengan kemampuan peneliti mengumpulkan dan menganalisis data.

Pada penelitian ini peneliti melakukan pengamatan, membuat catatan lapangan, mendeskripsikan proses pembelajaran dan memetakan data yang terkumpul. Analisis Data yang digunakan ada 2 data, yaitu: hasil belajar aspek kognitif dan hasil belajar aspek psikomotorik.

Analisis data hasil belajar aspek kognitif dilakukan secara deskriptif. Indikator Kinerja yang ditetapkan adalah: Siswa dikatakan berhasil dalam belajar aspek kognitif apabila perolehan nilai rata-rata ulangan $\geq 75$ (sama dengan atau di atas KKM yang ditetapkan yaitu 75. Indikator aspek kognitif meliputi: (1) pengetahuan umum tentang perpetaan; (2) unsur-unsur yang harus ada pada sketsa dan peta wilayah; (3) penerapan simbol yang menggambarkan objek geografi; (4) manfaat dan penerapan sketsa dan peta wilayah bagi kehidupan masa kini.

Siswa dikatakan berhasil apabila perolehan nilai aspek psikomotorik rata-rata 
memperoleh kualifikasi minimal baik (B) dengan rentang nilai (71-85). Indikator aspek psikomotorik meliputi: (1) kemampuan siswa mengumpulkan data dari objek geografi yang ditemukan; (2) kemampuan siswa menempatkan objek geografi pada sketsa dan peta wilayah melalui simbol peta yang tepat; (3) kemampuan siswa mencantumkan unsur-unsur sketsa dan peta wilayah; (4) kemampuan siswa menyelesaikan tahap finishing yang bernilai estetis.

\section{HASIL DAN PEMBAHASAN}

Hasil belajar siswa KD 4.2 Membuat sketsa dan peta wilayah yang menggambarkan objek geografi pada pra-siklus baru mencapai nilai rata-rata 53,32 aspek kognitif dan aspek psikomotorik kategori Cukup (56-70). Hasil penelitian pra-siklus tercantum pada Tabel 1.

Tabel 1. Hasil Tes Aspek Kognitif Pra-siklus

\begin{tabular}{ccc}
\hline No. & Interval Nilai & F \\
\hline 1. & $86-100$ & 0 \\
2. & $71-85$ & 3 \\
3. & $56-70$ & 9 \\
4. & $41-55$ & 11 \\
5. & Nilai $\leq 40$ & 8 \\
\hline
\end{tabular}

Sejumlah $25,81 \%$ dari 31 siswa atau 8 siswa mendapatkan nilai $\leq 40$. Sejumlah 3 siswa mendapat nilai 71-85. Pada tes awal belum ada yang mencapai nilai dengan rentang nilai 86-100. Sebagian besar siswa (19 siswa atau 61,29\% terdiri dari 8 siswa dengan nilai $\leq 40$ dan 11 siswa dengan nilai 41-55 ) mendapat nilai $<56$. Nilai ideal yang ditentukan adalah 75, pembelajaran pra-siklus aspek kognitif masih perlu diperbaiki untuk mendapatkan nilai tuntas KKM secara individu maupun klasikal. Hasil belajar aspek psikomotorik KD 4.2 dapat dilihat pada Tabel 2.

Tabel 2. Skor Aspek Psikomotorik Pra-siklus

\begin{tabular}{lllll}
\hline No & $\begin{array}{r}\text { Deskripsi } \\
\text { Nilai }\end{array}$ & Skor Nilai & F & $\begin{array}{r}\text { Per } \\
\text { sen } \\
\text { tase }\end{array}$ \\
\hline 1. & Amat Baik & $86-100$ & 0 & 0 \\
2. & Baik & $71-85$ & 2 & 6,45 \\
3. & Cukup & $56-70$ & 12 & 38,71 \\
4. & Kurang & $41-55$ & 16 & 51,61 \\
5. & Sangat & $\leq 40$ & 1 & 3,23 \\
& kurang & & & \\
\hline \multicolumn{2}{c}{ Jumlah } & & & \\
\hline
\end{tabular}

Terdapat siswa yang mendapatkan nilai $\leq$ $40(3,23 \%)$, sebanyak $51,61 \%$ atau 16 siswa memperoleh nilai $41-55$, sebanyak $38,71 \%$ atau 12 siswa memperoleh nilai 56-70, dan terdapat 2 siswa $(6,45 \%)$ yang mendapat kategori baik dengan nilai antara 71-85. Pada aspek psikomotorik pra-siklus belum ada siswa yang memperoleh nilai amat baik rentang nilai antara 86-100. Kesimpulan yang didapat peneliti setelah membaca data kedua aspek tersebut, maka penelitian pra-siklus menunjukkan pembelajaran belum maksimal, siswa belum mampu menggambar sketsa dan peta wilayah secara abstrak di dalam kelas tanpa mendekat ke objek geografi yang berada dilingkungan sekolah.

Pada Siklus I menggambarkan dari 31 siswa tidak terdapat siswa yang memperoleh nilai kurang dari 40. Sebanyak 5 siswa memperoleh skor 41-55 (16,13\%). Sebanyak $38,71 \%$ atau 12 siswa memperoleh skor 56-70. Siswa yang memperoleh skor 71-85 sebanyak 12 siswa $(38,71 \%)$. Pada Siklus I ini sudah terdapat 2 siswa yang memperoleh nilai $86-100(6,45 \%)$. Berdasarkan hasil observasi yang dilakukan peneliti, pembelajaran pada Siklus I pada aspek kognitif ada peningkatan dibanding Pra-siklus. Pada siklus II menggambarkan dari 31 siswa sebanyak $29,03 \%$ atau 9 siswa memperoleh skor 56-70. Sebanyak 58,07\% atau 18 siswa memperoleh skor 71-85, dan 4 anak memperoleh nilai 86-100 (12,90\%). Pada Siklus II ini tidak terdapat siswa yang memperoleh nilai 41-55 maupun $\leq 40$. Berdasarkan hasil observasi yang dilakukan peneliti, pembelajaran pada Siklus II pada aspek kognitif ada peningkatan dibanding dengan Siklus I.

Gambaran hasil penelitian aspek kognitif ketiga kondisi siklus dapat dilihat pada gambar 1 berikut. 


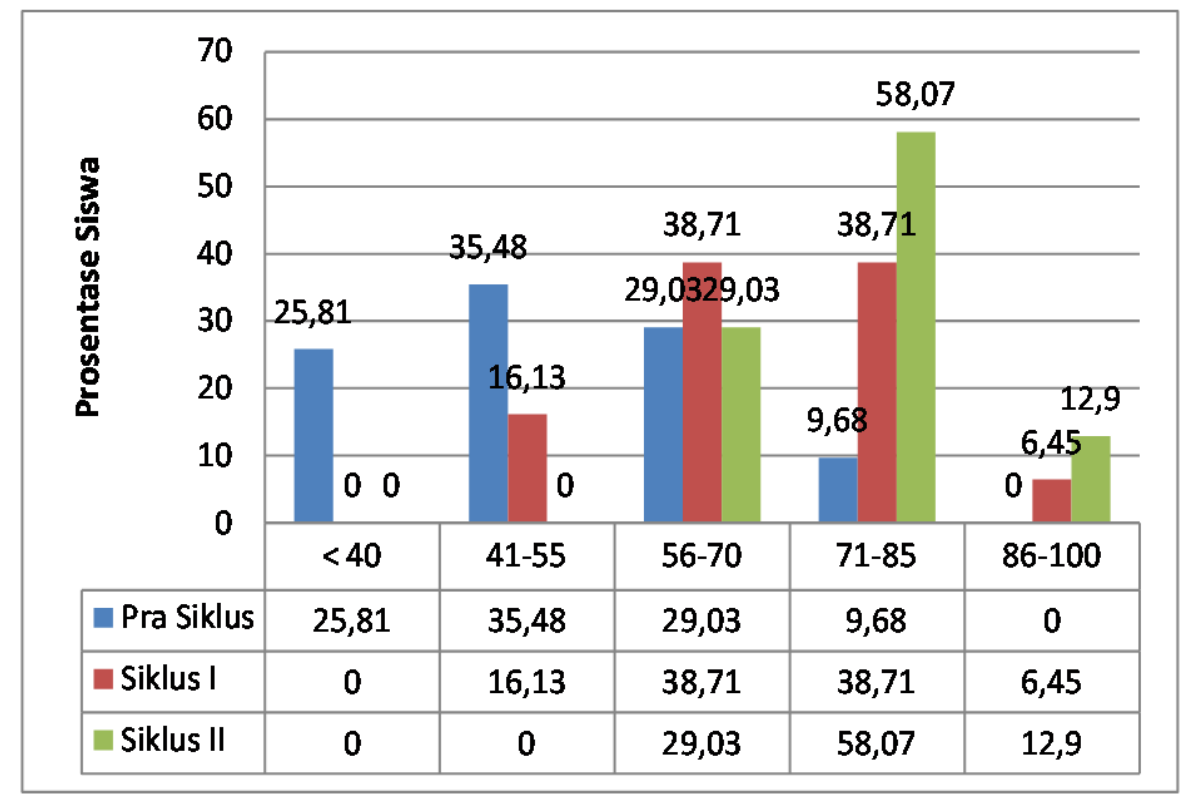

Gambar 1. Persentase Siswa yang Tuntas Penguasaan Aspek Kognitif

Observasi terhadap aspek psikomotorik siklus I menghasilkan temuan bahwa tidak terdapat anak yang memperoleh nilai $\leq 40$. Sebanyak 9,68\% dari 31 siswa atau 3 siswa mendapatkan nilai 41-55 pada. Sejumlah 12 siswa memperoleh nilai 56-70 (38,71\%). Siswa yang mendapat nilai 71-85 paling banyak dicapai dari 31 siswa ada 16 anak $(51,61 \%)$ dan belum ada siswa yang kategorinya amat baik. Kesimpulan yang didapat peneliti setelah membaca data kedua aspek tersebut, maka penelitian pada Siklus I dengan penerapan metode survei lapangan semakin meningkat di bandingkan dengan Pra-siklus.

Aktivitas dan antusias siswa dalam melakukan kegiatan survei lapangan tampak meningkat dibandingkan bila siswa hanya belajar di ruang kelas. Proses pembelajaran menyenangkan karena siswa bertambah pengalamannya dengan menemukan secara langsung objek geografi Pada siklus II dapat di deskripsikan bahwa sudah tidak terdapat siswa yang memperoleh nilai $\leq 40$ atau 41-55. Sebanyak $6,45 \%$ atau 2 siswa mendapatkan nilai 56-70. Frekuensi terbanyak dicapai siswa pada rentang nilai $71-85$ sejumlah 26 siswa $(83,87 \%)$ dari seluruh siswa sejumlah 31 siswa, sedangkan nilai tertinggi dicapai oleh 3 anak $(9,68 \%)$ dengan skor 86-100. Kesimpulan yang didapat peneliti pada kegiatan observasi dari data kedua aspek tersebut, semakin meningkat pada Siklus II.
Proses pembelajaran juga meningkat dan menyenangkan dengan menambah wawasan pengetahuan tentang peta digital melalui internet dan manfaat menggunakan Google Map dan GPS. Gambaran perbandingan hasil observasi aspek psikomotorik siklus I dan siklus II dapat dilihat pada tabel 3 .

Tabel 3. Hasil Penilaian Psikomotorik Siklus I dan Siklus II

\begin{tabular}{|c|c|c|c|}
\hline \multirow[t]{2}{*}{ No } & \multirow{2}{*}{$\begin{array}{c}\text { Aspek } \\
\text { Psikomotorik }\end{array}$} & \multicolumn{2}{|c|}{ Skor } \\
\hline & & Siklus I & Siklus II \\
\hline 1 & $\begin{array}{l}\text { Kemampuan } \\
\text { mengumpulkan } \\
\text { data }\end{array}$ & 78,6 & 92,0 \\
\hline 2 & $\begin{array}{l}\text { Kemampuan } \\
\text { menempatkan } \\
\text { simbol }\end{array}$ & 72,0 & 78,6 \\
\hline 3 & $\begin{array}{l}\text { Kelengkapan } \\
\text { unsur sketsa dan } \\
\text { peta }\end{array}$ & 64,6 & 70,0 \\
\hline 4 & $\begin{array}{l}\text { Kemampuan } \\
\text { menyelesaikan } \\
\text { gambar }\end{array}$ & 68,0 & 77,4 \\
\hline & Nilai terendah & 55 & 70 \\
\hline & Nilai tertinggi & 85 & 95 \\
\hline & Nilai rata-rata & 70,81 & 79,52 \\
\hline & etuntasan klasikal & $51,61 \%$ & $93,55 \%$ \\
\hline
\end{tabular}

Gambaran persentase peningkatan aspek psikomotorik siswa pada ketiga kondisi siklus dapat dilihat pada gambar 2 . 


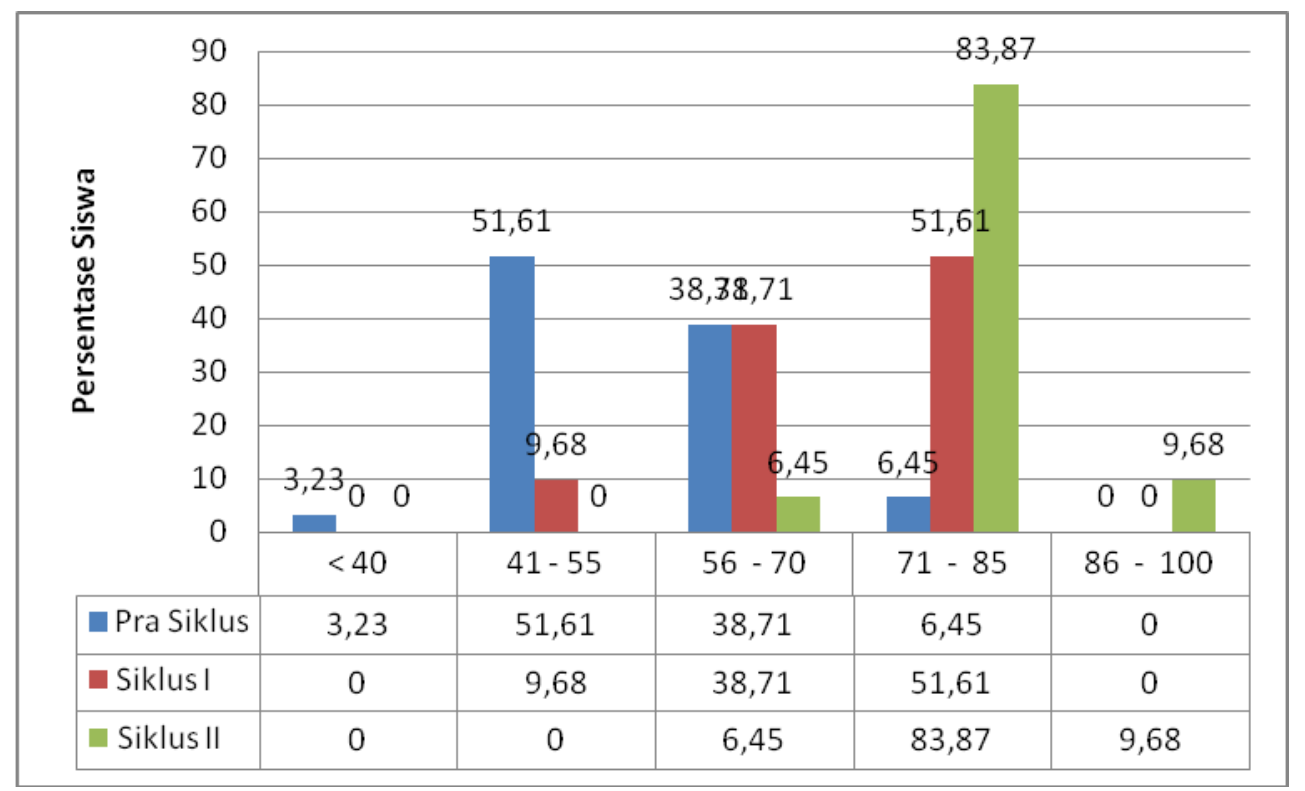

Gambar 2. Persentase Siswa yang Tuntas Aspek Psikomotorik

Pengalaman siswa belajar membuat sketsa dan peta wilayah merupakan pengalaman baru yang dilakukan siswa secara mandiri dengan melalui belajar penemuan (discovery). Siswa terus dilatih untuk memiliki keberanian mencoba, bekerjasama dalam kelompoknya, aktif melakukan pengamatan, berkreasi, dan mengevaluasi hasil kerja kelompoknya hingga akhirnya mampu membuat produk sketsa dan peta wilayah dengan baik, benar, bernilai estetis sesuai aturan kartografis. Penerapan metode survei lapangan dalam pembelajaran IPS khususnya materi sketsa dan peta wilayah memiliki manfaat bagi siswa terbukti dari hasil belajar pada aspek kognitif dan psikomotorik yang meningkat. Hal tersebut sejalan dengan teori belajar konstruktivisme yang dikutip oleh Dewanto bahwa pengetahuan siswa di bentuk karena mereka belajar aktif dari pada mereka yang hanya pasif/uninteresting (Dewanto, 2005).

Metode survei lingkungan yang dilakukan juga sesuai dengan pendekatan Learning Community dengan berusaha menggeser pembelajaran yang bersifat individual menjadi pembelajaran yang bersifat sosial. Ini berarti iklim kompetitif dalam kelas diubah menjadi iklim sosial dengan peran guru yang berusaha menciptakan iklim belajar dalam satu kelompok belajar. Penerapan pendekatan Learning Community dilakukan oleh Maskup (2017) menghasilkan temuan bahwa dengan menggunakan pendekatan Learning Community dapat meningkatkan motivasi dan prestasi belajar siswa kelas VIIA SMP Negeri 2 Gabus tahun 2015/2016.
Penelitian yang dilakukan oleh Maskup (2017) memiliki kemiripan dengan penelitian ini yaitu terletak pada pengalaman belajar siswa dalam berkomunikasi dan belajar berinteraksi dengan sesama teman, dengan kelompoknya, lingkungan alam, guru dan dengan masyarakat sekitar sebagai sumber belajar. Penelitian yang dilakukan oleh Astutiningrum menghasilkan temuan bahwa penggunaan data base monografi desa dapat meningkatkan pemahaman konsep peta wilayah. Penggunaan data base secara optimal dapat meningkatkan prestasi belajar siswa, terbukti nilai rata-rata yang diperoleh siswa meningkat dari 54,55 - 61,23 - 76,35 (Astutiningrum, 2014). Perbedaan dengan penelitian yang dilakukan peneliti terletak pada sumber data yang digunakan. Penelitian yang dilakukan Astutiningrum menggunakan sumber data media data base monografi desa, sedangkan pada penelitian yang peneliti lakukan menggunakan sumber data peta desa yang dipajang di ruang Kepala Desa. Persamaan dengan penelitian yang dilakukan peneliti terletak pada pokok bahasan yang dikaji yaitu peta wilayah.

Penelitian yang sama tentang Peta juga dilakukan oleh Warijan (2017) dengan temuan bahwa hasil belajar siswa SD kelas VI dapat ditingkatkan melalui penggunaan Peta. Rata-rata kelas mengalami kenaikan dari berturut-turut dari pra-siklus, siklus I dan silus II yaitu 57,9269,00 - 81,66. Susiloningsih (2010) dalam penelitiannya yang berjudul "Penggunaan Media Peta dalam Meningkatkan Prestasi Belajar IPS pada siswa kelas V SD Kutowinangun 09 Salatiga" menghasilkan temuan bahwa 
penggunaan media peta dapat meningkatkan prestasi belajar IPS siswa kelas V SD Kutowinangun 09 Salatiga. Penelitian yang dilakukan dalam 2 siklus dan target yang diharapkan adalah $85 \%$ siswa tuntas KKM yaitu memperoleh nilai sama atau di atas 60 .

Kedua peneliti tersebut memiliki kesamaan yaitu terletak pada materi Peta, namun perbedaannya terletak pada teknik yang digunakan. Pada penelitian Warijan (2017) dan Susiloningsih (2010) Peta yang digunakan adalah Peta Umum yang sudah jadi, sedangkan pada penelitian ini jenis peta yang dihasilkan adalah Peta Khusus dan Sketsa yang dibuat sendiri oleh siswa melalui bimbingan dan latihan dari guru dengan menilik langsung objek yang tergambar di Peta melalui metode survei lapangan.

Penggunaan metode survei lapangan sangat efektif dalam pembelajaran IPS pada KD 4.2 Membuat sketsa dan peta wilayah yang menggambarkan objek geografi. Hal tersebut seperti dikemukakan oleh beberapa tokoh seperti Vygotsky mengemukakan teori bahwa siswa belajar melalui interaksi dengan orang dewasa dan teman-teman yang lebih mampu (Suprijono, 2010:34). Piaget dan David Ausubel mengemukakan teori belajar bermakna, merupakan suatu proses mengkaitkan informasi baru pada konsep-konsep relevan yang terdapat pada struktur kognitif seseorang (Trianto, 2007:25). Pada proses belajar siswa harus aktif melakukan kegiatan, aktif berpikir, menyusun konsep dan memberi makna tentang hal-hal yang sedang di pelajari. Melalui penggunaan metode survei lapangan dapat meningkatkan hasil belajar siswa aspek kognitif dan psikomotorik dalam membuat sketsa dan peta wilayah yang menggambarkan objek geografi bagi siswa kelas VIIB SMP Negeri 2 Jakenan Kabupaten Pati Tahun 2015/2016.

Penerapan metode survei lapangan perlu sesekali dilaksanakan namun pelaksanaannya perlu perencanaan yang matang agar tidak mengganggu proses pembelajaran. Penerapan pembelajaran dengan metode survei lapangan awalnya terlihat kurang efektif karena siswa belum fokus ketika belajar di luar kelas, di alam terbuka, mereka masih melihat lingkungan sekitar yang merupakan pengalaman yang baru bagi siswa. Akan tetapi, dengan pengarahan dan bimbingan dari guru akhirnya siswa mampu mengeksplorasi pengetahuan mereka sendiri, mengkonstruksi bahkan mampu mengaplikasikan pengetahuannya dalam kehidupan sehari-hari, sehingga motivasi belajarnya menjadi meningkat. Hal tersebut di atas, sesuai dengan teori belajar yang dikemukakan oleh David Ausubel. David Ausubel menekankan agar guru mengetahui konsep-konsep yang telah dimiliki oleh siswa sehingga proses pembelajarannya dikatakan bermakna bagi siswa. Teori dalam belajar bermakna pengetahuan harus dikaitkan dengan konsep-konsep relevan yang sudah ada dalam struktur kognitif (otak) siswa. Penerapan metode survei lapangan dapat meningkatkan kemampuan ranah kognitif meliputi aspek: pengetahun/ingatan, pemahaman, dan aplikasi; kemampuan ranah psokomotorik berkenaan hasil belajar keterampilan meliputi aspek: gerakan, refleksi dan keterampilan gerak dasar.

\section{SIMPULAN}

Simpulan yang di dapat dari penelitian ini adalah: (a) Hasil belajar siswa aspek kognitif dalam membuat sketsa dan peta wilayah yang menggambarkan objek geografi dapat ditingkatkan melalui penerapan metode survei lapangan; (b) hasil belajar siswa aspek psikomotorik dapat ditingkatkan melalui penerapan metode survei lapangan; (c) peningkatan hasil belajar siswa aspek kognitif dari nilai rerata pra siklus, siklus I dan siklus II adalah 53,32- 69,19-78,55; peningkatan hasil belajar siswa aspek psikomotorik dalam membuat sketsa dan peta wilayah yang menggambarkan objek geografi Pra-siklus rerata 58,00 masuk kategori cukup (C) dalam rentang nilai (56-70). Siklus I rerata 70,81 masih masuk kategori cukup. Siklus II rerata 79,52 masuk pada kategori baik (B) dalam rentang nilai (71$85)$.

Implikasi dari peneliti ini adalah: Pertama, bagi siswa, dapat meningkatkan kualitas pembelajaran melalui metode survei lapangan. Kedua, bagi guru dapat memotivasi guru lain untuk mengembangkan keprofesionalannya dalam meningkatkan kualitas pembelajaran dan pengembangan kariernya. Ketiga, bagi sekolah dan dunia pendidikan, memberi kekayaan penggunaan metode yang variatif dengan melihat daya dukung lingkungan sekitar sekolah sebagai sumber belajar secara contextual learning.

Saran yang dapat direkomendasi adalah Guru hendaknya merancang pembelajaran inovatif dengan melihat daya dukung lingkungan sekitar seperti penggunaan Peta Desa yang ada di Balai Desa sebagai sumber belajar, lingkungan alam yang menunjang tercapainya kompetensi dasar. Penerapan variasi metode, strategi atau menciptakan sendiri media peta wilayah dapat meningkatkan hasil belajar siswa secara kognitif, afektif maupun psikomotorik. 


\section{DAFTAR PUSTAKA}

Astutiningrum. 2014. "Peran Penting Media Pembelajaran Data Base Monografi Desa bagi Penguasaan Konsep IPS Materi Peta Wilayah kelas VI SD Warurejo Kabupaten Tegal Tahun Pelajaran 2013/2014".Jurnal Pendidikan Kreatif 1 (2).

Dewato. 2005. Tinjauan Filosofis dan Praktis Metodologi Penelitian. Semarang: UNNES Press.

Maskup. 2017. "Peningkatan Motivasi dan Prestasi Belajar IPS melalui Pendekatan Learning Community pada Siswa Kelas VIIA SMP N 2 Gabus Tahun Pelajaran 2015/2016". Jurnal Pendidikan Siklus Media Pengembangan Profesi Guru 1 (1) 2017.

Sanjaya,Wina. 2009. Strategi Pembelajaran Berorientasi Standar Proses Pendidikan. Jakarta: Kencana Prenada Media Group.

Setiadi, Gunawan. Petunjuk Praktis Pelaksanaan PTK untuk Guru. 2014. Modul. Tidak diterbitkan.
Suprijono, Agus. 2010. Cooperative Learning. Yogyakarta: Pustaka Pelajar.

Susiloningsih. 2010. Penggunaan Media Peta dalam Meningkatkan Prestasi Belajar IPS pada Siswa Kelas V SD Kutowinangun 09 Salatiga Semester I tahun pelajaran 2009/2010. Skripsi. Salatiga: UKSW.

Trianto. 2007. Model-model Pembelajaran Inovatif Berorientasi Konstruktivistik. Jakarta: Prestasi Pustaka.

Warijan. 2017. “Upaya Peningkatan Hasil Belajar IPS melalui Penggunaan Peta bagi Siswa Kelas VII SDN Tanjunganom 01 Semester I Tahun Pelajaran 2015/2016".

\section{BIODATA}

Woro Kristiningtyas, S.Pd., M.Pd., NIP. 197303151998022 002. Pangkat: Pembina Tk I, IV/b. Guru IPS SMP Negeri 2 Jakenan yang mendapat tugas tambahan sebagai Wakil Kepala Sekolah bidang kurikulum. Penulis lahir di Pati, 15 Maret 1973. Alamat: Ds. Glonggong Rt 3 / Rw II Kec. Jakenan Kab. Pati 59182. No HP: 081325294950.

e-mail: worokristiningtyas@yahoo.co.id 